NBER WORKING PAPER SERIES

\title{
DEMOCRACY AND DEVELOPMENT: THE DEVIL IN THE DETAILS
}

\author{
Torsten Persson \\ Guido Tabellini \\ Working Paper 11993 \\ http://www.nber.org/papers/w11993
}

\author{
NATIONAL BUREAU OF ECONOMIC RESEARCH \\ 1050 Massachusetts Avenue \\ Cambridge, MA 02138 \\ January 2006
}

Prepared for the American Economic Review 2006 Papers and Proceedings. Persson: Institute for International Economic Studies, Stockholm University. E-mail: torsten.persson@iies.su.se. Web: http://www.iies.su.se/ perssont/. Tabellini: IGIER, Universita Bocconi. E-mail: guido.tabellini@unibocconi.it. Web: http://www.igier.uni-bocconi.it/tabellini. We thank Tim Besley and Ben Olken for useful comments, David von Below, Elena Besedina, and Giovanna D'Adda for research assistance and Christina Lönnblad for editorial assistance. Financial support from the Swedish Research Council, the Tore Browald Foundation, Bocconi University, the Italian Ministry of University and Research, and CIAR is gratefully acknowledge. The views expressed herein are those of the author(s) and do not necessarily reflect the views of the National Bureau of Economic Research.

(C2006 by Torsten Persson and Guido Tabellini. All rights reserved. Short sections of text, not to exceed two paragraphs, may be quoted without explicit permission provided that full credit, including (C) notice, is given to the source. 
Growth, Initial Conditions, Law and Speed of Privatization in Transition Countries: 11 Years

Later

Torsten Persson and Guido Tabellini

NBER Working Paper No. 11993

January 2006

JEL No. P0, O1, E0

\begin{abstract}
$\underline{\text { ABSTRACT }}$
Does democracy promote economic development? We review recent attempts to address this question, which exploit the within-country variation associated with historical transitions in and out of democracy. The answer is positive, but depends - in a subtle way - on the details of democratic reforms. First, democratizations and economic liberalizations in isolation each induce growth accelerations, but countries liberalizing their economy before extending political rights do better than those carrying out the opposite sequence. Second, different forms of democratic government and different electoral systems lead to different fiscal trade policies: this might explain why new presidential democracies grow faster than new parliamentary democracies. Third, it is important to distinguish between expected and actual political reforms: expectations of regime change have an independent effect on growth, and taking expectations into account helps identify a stronger growth effect of democracy.

Torsten Persson

Institute for International Economic Studies

Stockholm University

S-106 91 Stockholm

SWEDEN

and NBER

torsten.persson@iies.su.se
\end{abstract}


Richer countries are generally democratic. But this could reflect reverse causation or omitted variables. Evidence that democratizations yield subsequent economic growth is quite weak. Political regimes may still influence economic development, but the effects appear difficult to identify from the within-country variation. A plausible reason for this difficulty is that "democracy" is too blunt a concept. Political regimes come in various forms and are reformed in different circumstances. This paper illustrates three specific instances where the details of democratic reform influence their economic effects.

Section I zooms in on the interplay between democratizations and economic liberalizations. Both induce accelerations of growth, but the sequence of reforms is crucial: countries liberalizing their economy before extending political rights do better. Section II considers different forms of democracy. Specific democratic institutions influence the fiscal and trade policies implemented after democratization, which may explain why presidential democracy leads to faster growth than parliamentary democracy. Section III distinguishes expected and actual political reforms. Taking expectations of regime change into account helps identify a stronger growth effect of democracy.

We first we clarify our methodology. While political institutions are generally very persistent, they sometimes change suddenly and drastically - as in many democratizations or coups. Under appropriate identifying assumptions, such regime changes can be exploited by comparing average performance before and after the event. Our sample has annual observations for about 150 countries and includes about 120 regime changes over the period 1960-2000; in Section III, we backdate the panel to the mid-1800s, with twice as many 
regime changes. We classify a country as democratic if the polity 2 variable in the Polity IV data set is strictly positive. ${ }^{1}$ Per-capita income comes from the Penn World Tables for 1960-2000 and the Maddison data set for 1850-2000.

We estimate a panel regression:

$$
y_{i, t}-y_{i, t-1}=\beta y_{i, t-1}+\phi D_{i, t}+\boldsymbol{\rho} \mathbf{x}_{i, t}+\alpha_{i}+\theta_{t}+\epsilon_{i, t},
$$

where $y_{i, t}$ denotes $(\log )$ per capita income in country $i$ and year $t, D_{i, t}$ is a dummy variable equal to one under democracy, $\mathbf{x}_{i, t}$ is a vector of control variables, $\alpha_{i}$ and $\theta_{t}$ are country and year fixed effects. Thus, we estimate the parameter $\phi$ by difference in differences, where countries changing regime are the "treated", and those that do not are the "controls".

Identification requires that the selection of countries into democracy be uncorrelated with the country-specific and time-varying growth shock, $\epsilon_{i, t}$. This allows any correlation between regime selection and the country fixed effect, $\alpha_{i}-$ e.g., that fast-growing countries more likely become democratic than slow-growing ones. However, absent any regime change, average growth in reform countries should (counterfactually) have been the same as in nonreform countries (conditional on $\mathbf{x}_{i, t}$ ). A concrete case where we might confound economic and political reforms is the 1990s, when many formerly communist regimes introduced democracy as well as market economy. Therefore, we include in $\mathbf{x}_{i, t}$ a binary indicator for years after 1989 in the former Soviet bloc. We also include indicators for years of wars (current and lagged), as they are correlated with regime changes and growth. Most specifications also include dummy variables for continental location (Africa, Asia and Latin America) and socialist legal origin interacted with year dummy variables. To reduce serial correlation and allow for convergence, lagged per-capita income 
is always included.

Circumstances surrounding regime changes differ widely across time and location, as do the political institutions adopted or abandoned. Thus, the effects of a crude democracy indicator are likely to differ across observations. If we neglect this heterogeneity and estimate the average effect of democracy as in (1), $\epsilon_{i, t}$ also includes the term $\left(\phi_{i, t}-\phi\right) D_{i, t}$, where $\phi_{i, t}$ is the effect of democracy in country $i$ and year $t$. Identification of $\phi$ now requires the heterogeneous reform effect to be uncorrelated with its occurrence. This assumption fails if countries self-select into democracy based on the growth effect of regime changes (e.g., $D_{i, t}=1$ more likely when $\left.\phi_{i, t}>\phi\right)$. Below, we decompose the effects of political reforms according to observable features, one at a time. Studying the economic outcomes of specific types of reforms is relevant from a practical point of view, and as a test of specific hypothesis. This also makes identification of $\phi$ more credible by reducing unobserved heterogeneity; the relative effect of specific reforms can be identified under weaker assumptions than those needed to identify their average effect $\phi$.

\section{Economic liberalization and democracy}

This section draws on Giavazzi and Tabellini (2005). In Table 1, we start by estimating the average effect of democracy on growth, $\phi$ in (1). Column 1 suggests that becoming a democracy accelerates growth by 0.75 percentage points, a large and significant effect (the results are similar with standard errors clustered by country). With an estimated convergence rate of 6 percent per year (parameter $\beta$ in (1)), the long-run effect on income per capita is 12.5 percent. Controlling for years preceding and following the regime change does not affect the estimate, although growth slows down around the transition. 
Elias Papaioannou and Gregorios Siourounis (2004) and Dani Rodrik and Romain Wacziarg (2005) also show that democracy promotes growth.

Democratization is often associated with economic reforms, such as opening the economy to international trade and extending the role of markets. Sometimes economic liberalization leads democratization, more often it lags by a few years - perhaps because similar forces push for both kinds of reforms. Joint economic and political reforms could violate our identifying assumptions, however. Not controlling for economic reforms could bias upwards the estimated effect of democracy, via positive correlation between $D_{i, t}$ and $\epsilon_{i, t}$ in (1).

We use the same indicator of economic liberalizations as Giavazzi and Tabellini (the original source is Jeffrey Sachs and Andrew Werner, 1995) to estimate a multiple treatment equation. In column 2 , we thus include both the democracy and liberalization indicators. Both reforms retain a significant and positive effect on growth, with economic reform having the stronger effect.

Considering the joint effect of reforms lends additional credibility to the identifying assumption, but does not address heterogeneity in the sequence of reforms. Column 3 adds two dummy variables to the regression, which equal unity when democracy is enacted first or last, respectively, and equal zero when only one type of reform occurs. ${ }^{2}$ Countries where economic liberalization preceded democracy include South Korea, Taiwan, Chile and Mexico. The opposite sequence took place in countries as Argentina, Brazil, the Philippines and Bangladesh.

Enacting only one reform still has a positive and significant effect on 
growth, similar to those in columns 1 and 2. Moreover, the estimated coefficient of "democracy after liberalization" is positive and significant: the boost to growth from the two reforms is about 3.5 percent. But "liberalization after democracy" is negative and significant, implying an overall effect which is barely positive and statistically insignificant. Giavazzi and Tabellini (2005) show that this finding is very robust. A plausible interpretation is that young democracies in closed economic environments are more likely bogged down in redistributive conflict and populist policies, while young democracies in open economies are forced to pay more attention to economic efficiency. Moreover, opening the economy often goes hand in hand with securing the protection of property rights and enforcing the rule of law, which may be a prerequisite for a well-functioning democracy. Naturally, the usual caveats about identification apply. Naturally, the usual caveats about identification apply. But if the estimates do uncover a causal effect, reformers of closed autocracies ought to give priority to economic over political liberalization.

\section{Forms of democracy}

This section draws on Persson (2005), who studies heterogeneity in the kind of democratic institutions adopted or abandoned. Political scientists stress distinctions between different electoral rules and different forms of government. In our own recent research, we have shown that these constitutional forms imply systematic differences in economic policies. Do they also imply different growth effects of becoming a democracy?

Column 1 of Table 2 decomposes the average growth effect of democracy by adding two binary variables, one for the form of government (presidential vs. parliamentary), one for the electoral rule (majoritarian vs. proportional). 
Otherwise, the regression is identical to column 1 of Table $1 .^{3}$ The coefficient on democracy now picks up the default effect of becoming a presidential and majoritarian democracy. A new parliamentary democracy grows 1.5 percentage points less than a new presidential democracy and about 0.5 points less than a previous autocracy, although the latter estimate is not significantly different from zero. The electoral system has no influence on the growth effect of democracy.

A possible explanation for these results is induced policy changes. Based on cross-sectional estimates within a sample of democracies, Persson and Tabellini $(2003,2004)$ found that parliamentary and proportional democracies have larger government spending. In column 2, we estimate the effect on government consumption with the difference-in-difference specification in (1). ${ }^{4}$ A new majoritarian and presidential democracy cuts government consumption by almost 2 percent of GDP, while a new parliamentary democracy raises it considerably. The difference in spending between the two forms of government is a highly significant 5 percent of GDP. This estimate only exploits time variation in countries that enter and exit democracy, but is remarkably similar to our earlier estimates. Proportional rather than majoritarian elections raise spending by 1 percent of GDP. This effect is statistically significant but smaller than our previous cross-sectional estimates, probably due to the exclusion of transfers (we found that electoral rules have particularly strong effect on welfare-state spending).

How about other polices? Persson (2005) argues that since parliamentary and proportional democracies seek consensus among broader coalitions of voters, they should not only have larger government spending, but also less 
protectionist trade polices. In column 3, we thus estimate the effect on the liberalization indicator used in Section I. Introducing parliamentary or proportional democracy each raises the probability of a subsequent liberalization by about 10 percentage points, compared to majoritarian and presidential democracy.

These policy outcomes may explain the growth effects. A new parliamentary democracy is more prone to pursue economic liberalizations than a new presidential democracy. But as we saw earlier, liberalizations following democratizations have weaker effects on growth. ${ }^{5}$ At the same time, parliamentary democracies raise government consumption much more than presidential democracies. If this spending binge distorts economic activity, growth may suffer. While the electoral system also shapes policy, the spending binge in proportional democracies is smaller and may not show up in the growth rate.

\section{Expected and actual democracy}

This section draws on Persson and Tabellini (2005). If democracy has positive growth effects it raises the returns to investment. As investment reacts to expectations, both actual and expected regime changes affect growth. Growth would thus decelerate well before an imminent, and anticipated, coup. This would contradict our identifying assumption in (1), by creating a negative correlation between democracy, $D_{i, t}$, and the growth residual, $\epsilon_{i, t}$, and biases down our estimate of $\phi$ - the growth effect of democracy.

Motivated by this observation, Persson and Tabellini (2005) formulate a theoretical model of economic and political change, where countries stochastically enter and exit from democracy with probabilities influenced by 
current and lagged income. The probability of regime change also depends on a country's "democratic capital", which shapes the willingness of its citizens to stand up for democracy. Democratic capital accumulates in years of democracy and in countries with democratic neighbors, but depreciates under autocracy. Identification is achieved by an exclusion restriction derived in the model, namely that democratic capital has no direct effect on growth (given all the other controls).

We thus add to (1) the probability of regime change - in the form of a hazard rate - as estimated by Persson and Tabellini (2005). The growth equation is consistent with the estimated hazard rate and the sample is now 1850-2000. ${ }^{6}$ As country and year fixed effects are included, we estimate the effects of expected democracy entirely from the time variation in the hazard rate.

The first two columns of Table 3 report the estimated results within regimes, confining attention to observations under democracy only, or autocracy only. Under democracy, the probability of regime change hurts growth, consistent with the finding that democracy raises growth. The large negative estimated coefficient reflects the dimension of the estimated hazard rate, which is typically below 10\%, with an average of 3 . A fall in the hazard by 2 percentage points thus raises growth by about 0.5 percentage points. Similar effects are obtained by replacing growth with investment over the 1960-2000 sample. Under autocracy, the probability of regime change ought to spur growth. Instead, the coefficient is negative and insignificant. One interpretation is that we have omitted further heterogeneity, such that democratic reforms fail to boost economic performance in some autocracies. 
Alternatively, political uncertainty exerts an offsetting negative effect.

In column 3, we study actual as well as expected political regimes in the full sample, including the democracy dummy plus the probability of autocracy in the current period (also interacted with lagged democracy, allowing the effect of expectations to differ by regime). ${ }^{7}$ In addition to the exclusion restriction for democratic capital, identification relies on the usual identifying assumption $-\epsilon_{i, t}$ uncorrelated with $D_{i, t}$ - now made more credible by including the probability of autocracy as a regressor. This specification is demanding, as actual democracy and the probability of autocracy are highly collinear. Nevertheless, the results support the idea that expected as well as actual regime changes play a role. Actual democracy now induces a growth acceleration of over 1 percent. The estimated convergence rate (2.8 percent) implies a long-run income rise of 35 percent. This growth effect is larger than the benchmark estimate in Table 1. More importantly, it is also much larger than in the same specification over 150 years of data, where expectations are neglected (see Persson and Tabellini, 2005). Thus, including expected regime changes indeed brings out a more forceful effect of actual transitions on growth. The results in this section imply that stable and persistent democracy has a stronger effect on development than democracy per se.

Taken together, the results in our paper suggest that democracy is indeed too blunt a concept: the devil is in the details. Future theoretical and empirical work should pay close attention to the heterogeneity of political reforms. 


\section{References}

[1] Giavazzi, Francesco and Tabellini, Guido. "Economic and Political Liberalizations." Journal of Monetary Economics, 52, 2005, pp. 12971330.

[2] Papaioannou, Elias, and Siourounis, Gregorios. "Democratization and Growth." Mimeo, LBS, 2004.

[3] Persson, Torsten. "Forms of Democracy, Policy and Economic Development." NBER Working Paper, No. 11171, 2005.

[4] Persson, Torsten and Tabellini, Guido. The Economic Effects of Constitutions, MIT Press, Cambridge, US, 2003.

[5] Persson, Torsten and Tabellini, Guido. "Constitutional Rules and Fiscal Policy Outcomes." American Economic Review 94, 2004, pp. 2546.

[6] Persson, Torsten and Tabellini, Guido. "Democratic Capital: The Nexus of Political and Economic Change." Mimeo, IIES, 2005.

[7] Przeworski, Adam, Alvarez, Michael, Cheibub, Jose, and Limongi, Fernando. Democracy and Development: Political Institutions and Well-Being in the World 1950-1900, Cambridge University Press, 2000.

[8] Rodrik, Dani and Wacziarg, Romain. "Do Democratic Transitions Produce Bad Economic Outcomes?." American Economic Review 95, 2005, pp. 50-56. 
[9] Sachs, Jeffrey and Warner, Andrew. "Economic Reform and the Process of Global Integration." Brookings Papers on Economic Activity 1, 1995, pp. 1-118. 


\section{Notes}

${ }^{1}$ Large changes in polity 2 are generally clustered around 0. Although lower than that often chosen by political scientists, this threshold more easily captures the effect of discrete political reforms. We discard reforms in the last three years of the sample, setting to missing the observations of outcomes after such reforms. At the start of the sample, we only require one available observation before the reform.

${ }^{2}$ To unambiguously identify the sequence, Giavazzi and Tabellini (2005) only classify episodes that last at least four years as reforms, omitting temporary changes in political or economic institutions. The variables in column 3 of Table 1 use this classification, which differs slightly from that in the preceding columns for a few countries.

3 Table 2 assumes the effect of the form of government and the electoral system to be additive. The results are robust to relaxing this assumption.

${ }^{4}$ While Persson and Tabellini $(2003,2004)$ use IMF data for central government spending (including transfers), here we use Penn World Tables for central plus local government consumption, in percent of GDP.

${ }^{5}$ Indeed, all countries that first opened the economy, and then democratized, became presidential democracies, while the opposite sequence is observed for both forms of government.

6 The specification of the hazard rate includes democratic capital, lagged per capita income, a dummy variable for war years (current and lagged), dummy variables for democracy at independence, colonial origin, geographic location, socialist legal origin, and a linear and quadratic time trend.

${ }^{7}$ Adam Przeworski et al (2000) consider the effect of expected regime changes 
on economic growth in the post war period. 


\section{Table 1 Effects of political and economic reforms on economic growth}

\begin{tabular}{lccc} 
& $(1)$ & $(2)$ & $(3)$ \\
\hline Democracy & $0.75^{* *}$ & $0.81^{* *}$ & $0.70^{*}$ \\
& $(0.34)$ & $(0.33)$ & $(0.33)$ \\
Liberalization & & $0.92^{* *}$ & $1.22^{* * *}$ \\
& & $(0.39)$ & $(0.43)$ \\
Democracy after & & & $1.62^{*}$ \\
liberalization & & & $(0.86)$ \\
Liberalization after & & & $-1.71^{* * *}$ \\
democracy & & & $(0.62)$ \\
& & & \\
N. of countries & 138 & 130 & 130 \\
N. of observations & 4338 & 4229 & 4229
\end{tabular}

Notes: Robust standard errors in parentheses: ${ }^{*}$ significant at $10 \%$;* significant at $5 \%$; ${ }^{* * *}$ significant at $1 \%$. Specification described in text. 


\title{
Table 2 Forms of democracy, growth and economic policies
}

\author{
(1)
}

(2)

(3)

Growth Government Liberalization consumption

$\begin{array}{lccc}\text { Democracy } & 1.00^{* *} & -1.87^{* * *} & -0.07^{* * *} \\ & (0.51) & (0.54) & (0.02) \\ \text { Parliamentary } & -1.61^{* * *} & 4.89^{* * *} & 0.11^{* * *} \\ \text { democracy } & (0.59) & (0.79) & (0.04) \\ \text { Proportional } & 0.16 & 1.15^{* *} & 0.11^{* * *} \\ \text { democracy } & (0.49) & (0.49) & (0.03) \\ & & & \\ \text { N. countries } & 138 & 150 & 132 \\ \text { N. observations } & 4338 & 4552 & 4578\end{array}$

Notes: Robust standard errors in parentheses: * significant at $10 \%$; ** significant at $5 \% ;{ }^{* * *}$ significant at $1 \%$. Specification identical to that in Table 1, except that lagged income is excluded in cols 2 and 3. 


\section{Table 3 Expected democracy, actual democracy and growth}

(1)

(2)

Democracies Autocracies Full sample
Hazard rate out of
$-20.05^{* * *}$
$-17.85$
current regime
(5.51)
(11.93)

Democracy

Probability of

autocracy

Prob. of autocracy in

lagged democracy

N. countries

N. observations

3656 4130 8135

Notes: Robust standard errors in parentheses: significant at $10 \%$; ** significant at $5 \%$; ${ }^{* *}$ significant at $1 \%$. Control variables: country and year fixed effects, lagged income, dummy variable for wars and lagged wars, dummy variable for former socialist countries in Central and Eastern Europe plus former Soviet Union after 1990. Transition years excluded. 